\title{
Bureaucratic Reform in the Field of Human Resources Apparatus as the Main Capital in Realizing Good Governance
}

\author{
Galuh Rakasiwi \\ \{galuh.rakasiwi@gmail.com\} \\ Universitas Diponegoro, Indonesia
}

\begin{abstract}
Human Resource Apparatus is being foundation for the reform implementation in creating good governance. Purpose of the research to describe the bureaucratic reform strategy in the field of Human Resources Apparatus in order to achieve good governance. The author uses the method of library study by collecting data and information through the study of journals, books and literature as well as a source of reliable sources both written and digital related and relevant to this paper. The results indicate that there are several weaknesses in the condition of these human resources apparatus, first is about the low capacity of apparatus, apparatus's management which is not efficient. Because of that, need to be done a reform to get a professional, innovative, competent, transparent, serve, clean human resource apparatus and also free from corruption, collusion and nepotism to create a good governance. by (1) the strategy of human resource capacity development of personnel is carried out through CBHRM (Competency-Based HR Management), Competency Based Education and Training (PPBK) and assessment center methods and (2) Strategies in HR management of personnel are carried out through planning, management and quality improvement Transparency and accountability in HR personnel in accordance with the Strategic Plan and Road Map of Government Bureaucratic Reform.
\end{abstract}

Keywords: Collaborative Governance, Advocacy, Continuum of Care Policy, Women's, Children's Health Services

\section{Introduction}

Bureaucratic reform has been declared by the government in 2010 in the Grand Design of the Indonesian Bureaucratic Reform by issuing PP No. 81 of 2010. The goal is that all Ministries, Institutions and Local Governments have commitment and strength to start the process of implementing bureaucratic reform. So, in 2025, a professional and high integrity government bureaucracy can be realized [1]. Bureaucratic reform is a major of change or a radical change in the procedures for the implementation of public affairs as demands when administrative reform was blown in the 1980s [2].

Major changes (is about Bureaucratic Reform) must be carried out by all Ministries, Institutions and Local Governments, because the political reforms in 1989 known as the first wave of reforms, had not brought changes in the bureaucracy. In 2004, the government reaffirmed the importance of the principles of clean government and good governance in the context of providing excellent service to the community [1]. 
One of the central issues of good governance is the change in the government's capacity to respond and fight for the collective interests of the community based on the existing institutional corridors [3]. Therefore. It can also mean that good governance must be supported by two main aspects, namely civil society and economic society. Civil society means that all citizens have the right to control government operations. Meanwhile, the second aspect is presented by the bureaucracy and political institutions (political office). This aspect is in the spotlight, especially regarding the bureaucracy which includes the Human Resources Apparatus [4].

In line with [1] the main program that must be carried out in order to provide excellent service to the community to achieve good governance is to develop Human Resources apparatus through the application of bureaucratic reform. Human resources or commonly abbreviated as $\mathrm{HR}$ is the potential contained in human beings to realize their role as adaptive and transformative social beings who are able to manage themselves and all potentials contained in them to achieve prosperity in a balanced and sustainable order. HR is one of the key factors in economic reform, namely creating quality, skilled and highly competitive human resources in global competition $[5] .$.

Bureaucratic reform is directed at creating a clean, responsible, professional, efficient and effective bureaucratic apparatus, and creating an excellent service to the community. Conceptually, creating this starts from the redefinition of the vision, mission and strategy, the study of the separation and merger restructuring and the sharpening of functions, the study of the workload of organizational units. HR apparatus as a mover and organizer of government tasks play an important role in a government system. Therefore, the basic for complete the bureaucratic reform must start from reform of the management/management of the apparatus. The personnel management reform is an urgent need to be carried out in order to obtain a professional, innovative, responsive, open and serving and clean and corruption, collusion and nepotism free in apparatus. Most of the bureaucracy in Indonesia having convoluted, inefficient and laden public services, of course this is the biggest obstacle in improving the nation's competitiveness. To achieve a good form of governance, an ideal HR officer is needed. In addition, according to Bappenas [6] efforts to develop the HR capacity of the Apparatus until now is still cannot be managed properly. This was shown, among others, by the difficulty of change the mindset and the performance of the apparatus, the lack of discipline and employee ethics. A career system that was not yet entirely based on work performance, a remuneration system that was not sufficient for a decent life, recruitment that had not been done based on qualifications education needed, the implementation of education and training that have not been able to fully improve performance, weak supervision and auditing of apparatus performance, and staffing management information systems that have not functioned optimally. As a result of these various problems, the implementation of public services that is efficient and effective, that is fast, precise, inexpensive, and transparent has not yet been realized.

Professional apparatus is personnel who have an innovative and competent attitude, who are open and serving and who are clean and free of corruption, collusion and nepotism are expected to be able to compete in the global world, so the World Class Governance that have been vision of the bureaucratic reform in Indonesia could be works [7].

\section{Research Method}

This research uses the literature study method which carried by collecting data and information through study of journals, researches, books and literature from trusted sources that 
was spread by print and digital media that are relevant to this research. The aim of the research is to describe how is the performance of apparatus and how the Bureaucratic Reform is taking a challenge to manage Apparatus.

\section{Results and Discussion}

\subsection{Capacity of the Apparatus}

Apparatus is the main element of the government organization, no matter how good the arrangement of the authority and institutions, if it is not supported by a good apparatus, then the ideal bureaucracy will not be realized. The staffing problem that often found in the administration of bureaucracy is about selection of employees who are not transparent yet, not competitive yet and not fair yet. At the development stage, there are still many problems that related to the low performance of the Education and Training apparatus and confusing work directing. Another fact is appreciation for employees is still not appropriate and in line with the contributions made.

The major line is capacity of the apparatus in Indonesia currently has several problems [7], including:

a) The staffing management system based on merit system as mandated in Articles 7, 12 and 17 of Law Number 43 Year 1999 has not been implemented properly due to the lack of supporting instruments.

b) The distribution of civil servants has not been evenly distributed, indicated not in accordance with the existing workload.

c) The composition of existing employees has not/is not able to support the implementation of tasks and functions of the organization because it is not in accordance with their competencies.

d) Salary structure has not/cannot as a trigger for performance improvement because it is not related to performance, competence and responsibility.

This description gives us an indication that something is wrong in the management of the apparatus in Indonesia, which results in a lack of empowerment of civil servants in Indonesia. Staff management basically aims to manage all about staffing so that employee capabilities can be further improved so that they are more efficient and effective.

The strategy to improve the competency of the apparatus should not be seen partially but holistically. All elements need to be managed through the creation of the system, the application of the system consistently, and continuous improvement of the existing system, in order to produce a professional HR apparatus. The apparatus development strategy based on competency can be done through:

a) CBHRM (Competency-Based HR Management) strategy is one of the new strategies or approaches in mapping HR performance that leads to professionalism based on competencies, which are arranged in the competency directory and competency profile per position;

b) Competency Based Education and Training Strategy is an education and training system that offers efforts to improve the performance of HR and organizations through competencies that can create employees with abilities that match the needs and requirements of the job; 
c) Strategies that use the assessment center method, this is a process, procedure or approach method to assess and measure a person's competence. This strategy/method is one of the tools/tools for decision making related to human resources such as recruitment, promotion, transfer and career development of employees.

\subsection{Apparatus Management}

Organizations that are still fat, do not have proper functions and targets that makes authority overlaps. While authority is still widely abused and overlapping. Unclear work design also affects organizational productivity. From several research sources in the Ministry of PANRB, it explains that the Civil Servant management system has a number of fundamental weaknesses, including:

a) It emphasizes the administrative side than the management side.

b) More centralistic and less accommodative value of efficiency and effectiveness in achieving organizational goals in each institution both at central and regional levels.

c) There is no principle of check and balance in the implementation of staffing management, so it encourages duplication both at the central and regional levels then obstruct the accountability.

d) Not fully supported by staffing information system that makes negatively influences of the decision-making process in staffing management.

e) Not able to control and apply the principles of the merit system.

f) Does not provide space or legal basis for the appointment of non-career officials.

g) Does not properly accommodate about clarification of position and competency standards so it makes negative effects for the achievement of organizational and individual performance.

h) The existence of the State Personnel Commission is less independent and unclear.

The strategy that can be carried out in the framework of apparatus management is makes a clear planning, management and improvement of the quality of Apparatus in a transparent and accountable manner in accordance with the Strategic Planning and Road Map for Government Agencies. With concrete steps to identify, develop and uses employee competencies and align individual and agency goals. Thus, the main goal of the apparatus management to achieve excellence by making strategic allocations of qualified employees, so that increasing competitiveness in the international world will be achieved.

\subsection{Strategy for Enhancing the Quality and Competitiveness of Human Resources Apparatus by the Ministry of PANRB}

Apparatus as government human resources plays a role in realizing a good governance, as stated in Presidential Decree No. 18/2020 concerning the 2020-2024 RPJMN in order to provide quality public services. Currently human resources management has reached the third stage, namely talent management which has passed the first stage of the personnel section and the second stage regarding strategic HR. To accommodate this, Ministry of PANRB has issued PANRB ministerial regulation of number 3/2020 concerning Apparatus Talent Management.

It was explained that apparatus talent management is carried out by the government nationally in the context of accelerating national development carried out by central and regional agencies including (1) achieving strategic objectives of national development and improving the quality of public services; (2) preparing the best talents to fill key positions as future leaders; (3) encourage to increased professionalism; (4) strengthening and accelerating the 
implementation of the merit system in Government agencies; (5) placing the right apparatus in the right position; (6) balancing apparatus career development and agency need.

In a sense, apparatus talent management is an apparatus career management system that includes the stages of acquisition, development, retention and placement of talents that are prioritized to occupy target positions based on the highest level of potential and performance through certain mechanisms that are implemented effectively and sustainably to meet needs.

In improving the quality and competitiveness of human resources, there are five important points related to talent management. First, it is necessary to map and supply talent based on areas of expertise and profession. Second, managing a database of inventory and talent needs which manifest in a talent pool. Third, increasing skills, capacity and performance as well as career development and talent achievement. Furthermore, the creation of a conducive environment as an attraction for talent acquisition, development of potential, interests, expertise and talent achievement. Finally, the establishment of an Indonesian talent management agency that will be formed in a task force.

To carry out the 2020-2024 RPJMN, there are several strengthening that need to be done for the implementation of Apparatus Management. First, the application of national apparatus talent management so that Apparatus can have a career in various government agencies. Second, improving the merit system based on talent management and every government agency is encouraged to do this. Then related to the simplification of the echelonization that is being carried out. The simplification of the bureaucracy is important because it is part of strengthening the implementation of apparatus management. Finally, regarding the simplification of the bureaucracy, it is necessary to hold functional positions.

\subsection{The Challenge}

To facing the global challenges, the development of HR personnel is needed to refer into international competency standards (world class). The figure of the future apparatus must be professional and at the same time obey the law, rational, innovative, have high integrity and uphold public administration ethics in providing services to the public. Effendi [8] said that efforts to develop and utilize the apparatus include: (a) each civil apparatus must change its mindset, build character and identity, work professionally, and change the mindset, attitude pattern, and action patterns towards increasing work productivity; (b) formulating $4 \mathrm{C}$, which is a clear, pragmatic, comprehensive and innovative concept; competence as the basis for assignment, performance-based training; connections or clear linkages between subsystems; and commitment, know your mission, know your men, their strengths and weaknesses and keep your men informed/involved. Everything is accompanied by consistency and seriousness (shifting mindset); (c) formulating 4W (well plan, well organize, who bring what, well arrangement, and well control/supervision); (d) pay attention to $6 \mathrm{~W}$ (well select, educate, train, equip, and pay /paid) and implement $8 \mathrm{C}$ (commitment, concentration, capabilities, capacity, collaboration, commercialization, culture, and community), good governance, and develop to be a soulful bureaucrat's entrepreneur.

\section{Conclusion}

Based on the description above, there are several conclusions and recommendations can be drawn such as: 
a) A professional apparatus is needed. The apparatus should be innovative and have competent attitude, apparatus who are transparent and being a good civil servant as well as clean and free from corruption, collusion and nepotism. High attitude of the apparatus is needed in realizing good governance. However, in reality some of these ideal characteristics have not been realized. The obstacles related to Apparatus HR, including low HR capacity and weak HR management.

b) The strategy to develop the capacity of HR apparatus could be done by CBHRM (Competency-Based HR Management), Competency Based Education and Training (PPBK) and assessment center methods.

c) The strategy in apparatus HR management is carried out through planning, managing and improving the quality of the HR Apparatus into a transparent and accountable manner in accordance with the Government Agency's Strategic Planning and Road Map Reform.

\section{References}

[1] KemenPAN dan RB Republik Indonesia, Grand Desain Reformasi Birokrasi Indonesia 20102025. 2010, p. PP No. 81 Tahun 2010.

[2] G. E. Caiden, "What really is public maladministration?," Indian J. Public Adm., vol. 37, no. 1, pp. 1-16, 1991.

[3] Y. T. Keban, "Menuju Sistem Ketatalaksanaan Pemerintahan Yang Baik," Bahan Present. pada Diklatpim I Angkatan XXII LAN RI.

[4] T. Apriani, "Pengaruh Tenure KAP, Ukuran KAP, Spesialisasi Auditor, Audit Fee dan Workload Terhadap Kualitas Audit Dengan Dimoderasi Komite Audit (Studi Empiris Pada Perusahaan Manufaktur Yang Terdapat di Bursa Efek Indonesia Tahun 2015-2017),” J. Maksi, vol. 5, no. 1, 2020.

[5] A. B. Akny, "Mewujudkan Good Governance melalui Reformasi Birokrasi di Bidang SDM Aparatur untuk Peningkatan Kesejahteraan Pegawai" dalam Jejaring Administrasi Publik, Th," Jejaring Adm. Publik J. Ilmiah, Univ. Airlangga, vol. 6, no. 1, pp. 416-427, 2014.

[6] BAPPENAS, Lampiran Pidato Kenegaraan Presiden Republik Indonesia. Jakarta: Perum Percetakan Negara RI, 2017.

[7] K. Kismartini, "Sumber Daya Aparatur Modal Utama Mewujudkan Tata Kelola dan Kelembagaan dalam Meningkatkan Daya Saing Bangsa."

[8] T. Effendi, "Arah dan Strategi Pendayagunaan Aparatur Negara Dalam Rangka Efektivitas Pembangunan dan Terwujudnya Good Governance," J. Wacana Kinerja Kaji. Prakt. Kinerja dan Adm. Pelayanan Publik, vol. 10, no. 2, pp. 1-5, 2020. 